\title{
Effect of ovariectomy on serum prolactin concentrations in old and young rats
}

\author{
P. M. Wise, A. Ratner and G. T. Peake \\ Departments of Physiology and Medicine, University of New Mexico, School of Medicine, \\ Albuquerque, New Mexico 87131, U.S.A.
}

Summary. Changes in endogenous prolactin levels in rats with age and after ovariectomy varied according to the reproductive state, emphasizing the different mechanisms underlying infertility in rats in constant oestrus and prolonged dioestrus.

A decline in reproductive efficiency, as measured by the number of young per litter, the number of litters in a given period of time, or the regularity of the oestrous cycles, occurs in female rats at about 9-12 months of age (Ingram, 1959; Adams, 1972). At this time a female may be in (1) constant oestrus with follicular development but no ovulation, (2) prolonged dioestrus with hyperluteinized ovaries, or (3) prolonged dioestrus with atrophic ovaries. The results of several studies suggest that changes in the hypothalamic-pituitary axis are responsible for the reproductive failure. Electrical stimulation of the preoptic area of the hypothalamus (Clemens, Amenomori, Jenkins \& Meites, 1969) or injections of catecholamines (Quadri, Kledzik \& Meites, 1973; Huang \& Meites, 1975) can restore regular cycles in old rats which were previously in constant oestrus. The ovary is unlikely to be the primary site of dysfunction since transplantation of ovaries of senile rats to the kidney capsule of ovariectomized young rats resulted in resumption of oestrous cycles (Peng \& Huang, 1972).

An association between high prolactin levels and infertility has been shown for women (delPozo et al., 1974) and old rats (Mallampati \& Johnson, 1973; Ratner \& Peake, 1974; Shaar, Euker, Riegle \& Meites, 1975). Mallampati \& Johnson (1974) suggest that changes in hypothalamic control of prolactin secretion are closely associated with the age-related loss of reproductive function. In the present study the levels of prolactin in old and young rats in various reproductive states were determined and compared.

The Holtzman rats used were young cyclic females (4-5 months) and old 'retired breeders' (11-18 months). They were maintained in individual cages in a temperature-controlled environment $\left(22 \pm 1^{\circ} \mathrm{C}\right)$ with a $14 \mathrm{hr}$ light: $10 \mathrm{hr}$ dark lighting regimen (lights on at 06.30 hours). Purina rat chow and tap water were freely available. Vaginal smears were taken each morning between 09.00 and 10.00 hours. An old animal was considered as being in constant oestrus when large cornified cells appeared in the smear for at least 2 consecutive weeks; prolonged dioestrus was recognized when leucocytes appeared in the smear for at least 10 consecutive days. Some old females exhibited regular oestrous cycles. Young rats were used only after they had experienced at least 2 consecutive 4-day cycles.

All animals were anaesthetized with ether and ovariectomized. Blood samples were collected between 09.00 and 10.00 hours from the external jugular vein just before ovariectomy and 3 weeks later. The samples were refrigerated overnight and then centrifuged at $2000 \mathrm{~g}$ for $20 \mathrm{~min}$. Serum was separated and stored frozen at $-30^{\circ} \mathrm{C}$ until assay by the radioimmunoassay kit provided by the Rat Pituitary Program of the NIAMDD. All samples were assayed in duplicate at two dilutions.

A paired $t$ test was used to assess the differences between groups (Steel \& Torrie, 1960); differences between means were considered significant when $P<0.05$.

The ovaries of the old rats in prolonged dioestrus were all hyperluteinized when examined at the time of ovariectomy. As shown in Table 1, serum prolactin levels were twice as high in the old rats in constant oestrus as they were in the young oestrous rats $(P<0.001)$, but were lower in the old dioestrous rats than in the young animals (prolonged dioestrus, $P<0.01$; cyclic dioestrus, $P<0.05$ ). 
After ovariectomy there were no significant differences in the prolactin concentrations among the five groups of rats. Ovariectomy caused a significant fall in serum prolactin in old constant oestrous and young cyclic oestrous and dioestrous rats $(P<0.001, P<0.01, P<0.05$ respectively).

Table 1. The effect of ovariectomy on prolactin levels (ng NIAMDD-rat-RPl $/ \mathrm{ml}$ ) in old and young rats

\begin{tabular}{|c|c|c|c|c|c|}
\hline & \multicolumn{3}{|c|}{ Old rats } & \multicolumn{2}{|c|}{ Young rats } \\
\hline & $\begin{array}{c}\text { Cyclic } \\
\text { dioestrous }\end{array}$ & $\begin{array}{l}\text { Constant } \\
\text { oestrous }\end{array}$ & $\begin{array}{l}\text { Prolonged } \\
\text { dioestrous }\end{array}$ & Oestrous & Dioestrous \\
\hline No. of animals & 6 & 6 & 5 & 4 & 6 \\
\hline Before ovariectomy & $22 \cdot 9 \pm 7 \cdot 1$ & $152 \cdot 5 \pm 13 \cdot 5$ & $19 \cdot 1 \pm 3 \cdot 7$ & $71 \cdot 3 \pm 7 \cdot 5$ & $59 \cdot 7 \pm 9 \cdot 0$ \\
\hline After ovariectomy & $28 \cdot 6 \pm 8 \cdot 3$ & $19 \cdot 6 \pm 2 \cdot 2$ & $22 \cdot 9 \pm 3 \cdot 5$ & $19 \cdot 5 \pm 2 \cdot 3$ & $26 \cdot 1 \pm 4 \cdot 0$ \\
\hline Significance & N.S. & $P<\overline{0.001}$ & N.S. & $P<\overline{0} \cdot 01$ & $P<\overline{0} .05$ \\
\hline
\end{tabular}

These experiments support the concept that changes in prolactin secretion may be an important index in the ageing of the hypothalamic-pituitary-ovarian axis of the rat.

The high serum prolactin levels in the old rats in constant oestrus are comparable to those reported for rats in constant oestrus after androgen sterilization (Mallampati \& Johnson, 1973; Ratner \& Peake, 1974) and because of lesions in the hypothalamic suprachiasmatic region (Bishop, Fawcett, Krulich \& McCann, 1972). Increased ovarian oestrogen secretion is thought to be involved in maintaining these high prolactin levels, because concentrations of prolactin fell after ovariectomy (Bishop et al., 1972; Ratner \& Peake, 1974) and were enhanced after administration of oestrogen (Horrobin, 1973). The significantly lowered prolactin levels in all 3 groups of dioestrous rats in the present study support an association between oestrogen and prolactin concentrations. The lower prolactin levels in the older rats and the results of ovariectomy in all the animals provide further evidence that the prolactin levels are maintained by oestrogen secreted by the ovary.

The results of this experiment emphasize the importance of the different mechanisms in the decline of reproductive function in the rat. The changes in the endogenous levels of prolactin with age and the response to ovariectomy in terms of serum prolactin are clearly different in rats exhibiting constant oestrus and those showing prolonged dioestrus. Other studies have shown that ageing rats of these types respond differently to a variety of stimuli (Quadri et al., 1973; Huang \& Meites, 1975; Watkins, Meites \& Riegle, 1975). The results of experiments in which ageing rats are chosen at random without regard to the vaginal smear pattern of the individual (Debeljuk, Arimura \& Schally, 1972; Howland \& Preiss, 1975; Shaar et al., 1975) must, therefore, be reconsidered. Generalizations concerning ageing in the rat should take into consideration the possibility of multiple mechanisms resulting in the lack of cycles and infertility.

This research was supported by NSF Grant No. BMS71-01528 A02 (A.R.) and NIH Grant No. HD-AM-05794-04 (G.T.P.). We thank Ms Carolyn R. Sanborn and Ms Josephine A. Morris for expert technical assistance.

\section{References}

Adams, C.E. (1972) Aging and reproduction. In Reproduction in Mamnals. 4. Reproductive Patterns, pp. 127-156. Eds C. R. Austin \& R. V. Short. Cambridge University Press.

Bishop, W., Fawcett, C.P., Krulich, L. \& MCCANN, S.M. (1972) Acute and chronic effects of hypothalamic lesions on the release of $\mathrm{FSH}, \mathrm{LH}$ and prolactin in intact and castrated rats. Endocrinology $91,643-656$.
Clemens, J.A., Amenomori, Y., Jenkins, T. \& Meites, J. (1969) Effects of hypothalamic stimulation, hormones and drugs on ovarian function in old female rats. Proc. Soc. exp. Biol. Med. 132, 561563

Debeljuk, L., Arimuri, A. \& Schally, A.V. (1972) Studies on the pituitary responsiveness to luteinizing hormone releasing hormone. Endocrinology 90, $585-588$. 
delPozo, E., Varga, L., Wyss, H., Tolis, G., Friesen, H., Wenner, R., Vetter, L. \& UetTWiler, L. (1974) Clinical and hormonal response to Bromocriptin (CB 154) in the galactorrhea syndromes. J. clin. Endocr. Metab. 39, 18-26.

Horrobin, D.F. (1973) Prolactin: Physiology and Clinical Significance. MTP Medical and Technical Publishing Co., Lancaster, Great Britain.

Howland, B.E. \& Preiss, C. (1975) Effects of aging on basal levels of serum gonadotropins, ovarian compensatory hypertrophy and hypersecretion of gonadotropins after ovariectomy in female rats. Fert. Steril. 26, 271-276.

Huang, H. H. \& MeItes, J. (1975) Reproductive capacity of aging female rats. Neuroendocrinology 17, 289-295.

INGRAM, D.L. (1959) The vaginal smear pattern of senile laboratory rats. $J$. Endocr. 19, 182-188.

Mallampati, R.S. \& Johnson, D.C. (1973) Serum and pituitary prolactin, LH and FSH in androgenized and normal male rats treated with various doses of estradiol benzoate. Neuroendocrinology 11, 4656.

Mallampati, R.S. \& Johnson, D.C. (1974) Gonado- tropins in female rats androgenized by various treatments: prolactin as an index of hypothalamic damage. Neuroendocrinology 15, 255-266.

Peng, M.T. \& Huang, H.H. (1972) Aging of hypothalamic-pituitary-ovarian function in the rat. Fert. Steril. 23, 535-542.

QuadrI, S.K., KledziK, G.S. \& Meites, J. (1973) Reinitiation of estrous cycles in old constant estrous rats by central acting drugs. Neuroendocrinology 11, 248-255.

Ratner, A. \& Peake, G.T. (1974) Maintenance of hyperprolactinemia by gonadal steroids in androgensterilized and spontaneously constant estrous rats. Proc. Soc. exp. Biol. Med. 146, 680-683.

ShaAr, C.J., Euker, J.S., Riegle, G.D. \& Meites, J. (1975) Effects of castration and gonadal steroids on serum luteinizing hormone and prolactin in old and young rats. $J$. Endocr. 66, 45-51.

SteEL, R.G.D. \& TorRIE, J.H. (1960) Principles and Procedures of Statistics. McGraw-Hill Book Co., New York.

Watkins, B.E., Meites, J. \& Riegle, G.D. (1975) Agerelated changes in pituitary responsiveness to $\mathrm{LHRH}$ in the female rat. Endocrinology 97, 543-548.

Received 20 December 1975 